\title{
Ankara Koșullarında Hibrit Çerezlik Ayçiçeği (Helianthus annuus L.) Genotipinde Farklı Sıra Üzeri Aralıkları ve Azot Dozlarının Verim ve Verim Ögelerine Etkisi
}

\author{
Sibel DAY ${ }^{*}$ \\ Özer KOLSARICI \\ 'Ankara Üniversitesi Ziraat Fakültesi Tarla Bitkileri Bölümü, ANKARA
}

*Sorumlu yazar e-posta (Corresponding author e-mail) : day@ankara.edu.tr Gelis tarihi (Received) : 25.03.2014

Kabul tarihi (Accepted) : 23.06.2014

Öz

Bu araștırma, Ankara koșullarında uygulanan farklı sıra üzeri mesafe $(20 \mathrm{~cm}, 30 \mathrm{~cm}$ ve $40 \mathrm{~cm})$ ve azot dozlarının $\left(0,4,8\right.$ ve $\left.12 \mathrm{~kg} \mathrm{da}^{-1}\right)$ 03M 42 hibrit çerezlik ayçiçeği genotipinde verim ve verim ögeleri üzerine etkilerini belirlemek amacıyla 2007 ve 2008 yıllarında yürütülmüștür. Deneme, tesadüf bloklarında bölünmüș parseller deneme desenine göre üç tekrarlamalı olarak kurulmuștur. Araștırmada, bitki boyu, tabla çapı, bin tane ağılığı, kabuk oranı, bitkide tane verimi, hasat indeksi, dekara tane verimi, yağ oranı ve protein oranı özellikleri incelenmiștir.

Araștırma sonuçlarına göre, en uzun bitki boyu 157,2 cm ile $12 \mathrm{~kg} \mathrm{~N} \mathrm{da}^{-1}$ dozunda, en yüksek dekara tane verimi ise ikinci yılda $20 \mathrm{~cm}$ sıra üzeri aralıkta $12 \mathrm{~kg} \mathrm{~N} \mathrm{da-1}$ uygulamasında 410,3 kg da-1 olarak elde edilmiștir. Sonuç olarak, sıra üzeri aralığın daralması ve bununla beraber azot dozlarının da artması verim artıșına sebep olmuștur.

Anahtar Kelimeler: Azot dozu, çerezlik ayçiçeği, sıra üzeri aralık

\section{The Effect of Different Intra-Row Spacing and Nitrogen Levels on Yield and Yield Components of Hybrid Confectionery Sunflower (Helianthus annuus L.) in Ankara Conditions}

\begin{abstract}
This research was conducted at the experimental field of Department of Field Crops, Faculty of Agriculture, University of Ankara in 2007 and 2008. The aim of the research was to determine the effects of different intra-row spacings $(20,30$ and $40 \mathrm{~cm})$ and nitrogen doses $\left(0,4,8\right.$ and $\left.12 \mathrm{~kg} \mathrm{da}^{-1}\right)$ on yield and yield components of confectionery sunflower genotype 03M142. The experiment was laid on "Randomized Complete Block Design" as split plots with three replications. Plant height, head diameter, seed yield per head, 1000 seed weight, hull ratio, seed yield, oil ratio and protein ratio were investigated. According to the results observed in both years, the highest plant height was $157.3 \mathrm{~cm}$ at $12 \mathrm{~kg} \mathrm{~N} \mathrm{da}^{-1}$ and the highest seed yield was observed as $410.3 \mathrm{~kg} \mathrm{da}^{-1}$ at $20 \mathrm{~cm}$ intra-row spacing with $12 \mathrm{~kg} \mathrm{~N} \mathrm{da}^{-1}$ in the second year. Results revealed that decreased intra-row spacing and increased nitrogen doses led to increase of the seed yield.
\end{abstract}

Key Words: Nitrogen dose, confectionery sunflower, intra-row spacing

\section{Gíriș}

Ayçiçeği çerezlik olarak uzun zamandan beri kullanılmakta olup, dünyada yüzden fazla gıda çeșidinde; örneğin ekmek, pasta, dondurma, çikolata, kurabiye gibi yiyeceklerde iç olarak kullanılmaktadır (Lofgren, 1997).
Türkiye'de ve dünyada çerezlik ayçiçeği, önemli düzeyde gelir getiren bir ürün konumuna gelmiștir. Ancak ayçiçeği üzerine yapılan araștırma ve çalıșmaların geneli yağlık çeșitler üzerinde yoğunlașmıștır. Ayrıca istatistiksel olarak çerezlik 
ayçiçeğiyle ilgili verilere Türkiye'de ancak 2004 yılından itibaren ulașılabilmektedir. Çerezlik ayçiçeği Orta Anadolu Bölgesi için önemli bir bitki olmakla beraber 293.210 da ekim alanı ile Türkiye'de en fazla ekim bu bölgede yapılmaktadır (Anonim, 2014). Verim değerleri bakımından ise $127 \mathrm{~kg} \mathrm{da}^{-1}$ ile en düșük ikinci verime sahip bölgedir (Anonim, 2014). Verimin düșük olmasının çeșitli sebepleri bulunmaktadır. Bunların bașında ekimin yaklașık \% 65'inin kurak șartlarda sulanmadan yapılması ve bu alanlardaki verim ortalamasının (83 $\left.\mathrm{kg} \mathrm{da}^{-1}\right)$ bu bölgede sulu koșullarda yetiștirilen çerezlik ayçiçeğine (205 kg da ${ }^{-1}$ ) göre düșük olması sebebiyle verim ortalamasını düșürmesidir.

Azot (N) bitkiler için önemli bir bitki besin maddesi olup, uygulandığında toplam bitki gelișimini, verimi ve verim bileșenlerini etkilemektedir. Aynı zamanda azotlu gübrelemenin gereğinden fazla yapılmasının çevreye ve ekonomiye olumsuz etkileri bulunmaktadır. Ayçiçeği bitkisinin yüksek oranda azota intiyaç duyması sebebiyle, yüksek verim elde edebilmek, yeraltı sularının kirlenme derecesini azaltabilmek için uygun genotiplerin seçilmesi ve azotlu gübrelemenin gerekli ve uygun biçimde yapılması gerekmektedir (Montemurro ve De Giorgio, 2005).

Ayçiçeğinde verim artıșı büyük oranda azotlu gübrelemenin etkin biçimde ve uygun zamanlarda yapılmasına bağlıdır. Orta Anadolu'da çiftçiler ve çerez fabrikaları için önemi olan çerezlik ayçiçeği tarımının geliștirilebilmesi için uygun genotiplerin belirlenmesi ve verim artırıcı girdilerin etkin olarak uygulanması sağlanmalıdır. Uygun bitki sıklığının ayarlanması ve bitki besin maddelerinin noksan olduğu topraklara yeterli derecede gübre uygulamaları bitkilerden optimum verimi elde etmede gereklidir. Orta Anadolu koșullarında özellikle çerezlik ayçiçeğinde farklı sıra üzeri mesafeler ve azot dozlarının verim ve verim bileșenleri üzerine etkilerinin araștırıldığı çalıșmalar oldukça kısıtlıdır.

Bu çalıșma, çerezlik ayçiçeğinde uygun sıra üzeri aralıkların ve gerekli azot dozunun belirlenmesi amacıyla 2 yıl süreyle yürütülmüștür.

\section{MATERYAL VE YÖNTEM}

Ankara Üniversitesi Ziraat Fakültesi Tarla Bitkileri Bölümü'nde 2007 ve 2008 yıllarında yürütülen araștırmada, materyal olarak 03M142 hibrit genotipi ile \% 21 oranında $\mathrm{N}$ içeren amonyum sülfat gübresi kullanıımıștır.
Araștırmanın yürütüldüğü yıllara ve uzun yıllara ait bazı iklim verileri Çizelge 1'de özetlenmiștir. Çizelge l'de görüldüğü gibi, 2007 ve 2008 yıllarındaki aylık ortalama sıcaklık değerleri 9, 1-26,7 ${ }^{\circ} \mathrm{C}$ arasında değișmiștir. Çizelge 1' de görülen 2007 ve 2008 yıllarına ait ortalama yağıș değerleri ise 0$61,6 \mathrm{~mm}$ arasında değișim göstermiștir. Nispi nem ise 2007 ve 2008 yıllarında \% 29,8-54,8 arasında değișmiștir. Deneme alanına ait toprak hafif alkali, toplam tuz düzeyi zararsız, fosfor içeriği bakımından orta düzeyde, potasyumca zengin, azotça çok fakir olmayan, organik maddece yetersizdir (Çizelge 2).

Deneme üç tekerrürlü olarak tesadüf bloklarında bölünmüș parseller deneme desenine göre kurulmuștur. Denemede sıra üzeri aralıklar (20, 30 ve $40 \mathrm{~cm}$ ) ana parsellere, azot dozları ise alt parsellere $\left(0,4,8\right.$ ve $\left.12 \mathrm{~kg} \mathrm{da}^{-1}\right)$ gelecek șekilde yerleștirilmiștir. Ekim 5,2 m x 2,8 m=14,56 $\mathrm{m}^{2}$ boyutlarındaki parsellere sıra aralığı $70 \mathrm{~cm}$ olarak sabit tutularak 4 sıra halinde yapılmıștır. Azotlu gübre uygulamalarının yarısı ekimden önce, diğer yarısı da tabla olușumu bașlangıcında olacak șekilde yapılmıștır.

Ekim, 2007 yilında 26 Nisanda, 2008 yilında 15 Nisanda gerçekleștirilmiștir. Ekim 70 x $20 \mathrm{~cm}, 70$ x $30 \mathrm{~cm}$ ve $70 \times 40 \mathrm{~cm}$ bitki sıklığı ile ocak usulü yapılarak, her ocağa 3 tohum atımıș ve üzerleri kapatımıștır. Ekimden sonra merdane ile toprak yüzeyi bastırımıștır. Çıkıș tamamlandıktan sonra her ocakta sağlıklı ve normal görülen bir bitki kalacak șekilde tekleme yapılmıștır. Uygulanan azotlu gübre miktarları, azot dozları $0 \mathrm{~kg} \mathrm{da}^{-1}$ (kontrol), $4 \mathrm{~kg} \mathrm{da}^{-1}$, $8 \mathrm{~kg} \mathrm{da}^{-1}$ ve $12 \mathrm{~kg} \mathrm{da}^{-1}$ olacak șekilde parseller için hesaplanarak verilmiștir. Azot dozlarının ikinci yarısı minyatür tabla olușum (R1) döneminde (Schneiter ve Miller, 1981) parsellere verilmiștir. Bitkilerin toprak yüzeyine çıkıșından yaklașı iki hafta sonra tekleme ve el çapası yapılmıștır. Her iki yılda da görülen kuș yoğunluğu sebebiyle ekimden hemen sonra parsellerin üzeri file ile örtülmüștür. Denemenin her iki yılında da 2 kere yabancı otla mücadele için çapa yapılmıș ve ayrıca 2 kere sulama yapılmıștır.

Araștırma sonunda elde edilen verilerin değerlendirilmesi MSTAT-C paket programı kullanılarak yapılmıștır. Uygulamalar arasındaki farklııkların önem düzeylerini belirleyebilmek amacıyla Duncan Testi kullanıımıștır (Düzgüneș vd., 1987). 
Çizelge 1. Deneme alanının 2007 ve 2008 yılı iklim verileri*

Table 1. Average precipitation, temperature and relative humidity of 2007 and 2008

\begin{tabular}{|lccccccccc|}
\hline \multirow{2}{*}{ Aylar } & \multicolumn{3}{c}{ Yağıș $(\mathrm{mm})$} & \multicolumn{3}{c}{ Sıcaklık ( $\left.{ }^{\circ} \mathrm{C}\right)$} & \multicolumn{3}{c|}{ Nispi Nem (\%) } \\
\cline { 2 - 9 } & $\begin{array}{c}\text { Uzun yıllar } \\
\text { ort. }\end{array}$ & 2007 & 2008 & $\begin{array}{c}\text { Uzun } \\
\text { yıllar ort. }\end{array}$ & 2007 & 2008 & $\begin{array}{c}\text { Uzun } \\
\text { yıllar ort. }\end{array}$ & 2007 & 2008 \\
\hline Ocak & 33,1 & 39,0 & 20,1 & 0,7 & 1,2 & $-4,0$ & 76,5 & 76,0 & 76,3 \\
Șubat & 38,1 & 16,4 & 6,5 & 0,7 & 2,5 & 0,1 & 73,1 & 68,5 & 68,9 \\
Mart & 24,5 & 37,5 & 54,9 & 6,4 & 7,2 & 10,1 & 63,0 & 59,5 & 57,6 \\
Nisan & 39,8 & 23,8 & 32,7 & 12,6 & 9,1 & 13,7 & 57,8 & 53,7 & 54,8 \\
Mayıı & 47,9 & 17,9 & 45,4 & 16,1 & 20,4 & 15,5 & 56,6 & 41,1 & 50,9 \\
Haziran & 20,5 & 31,7 & 10,3 & 20,1 & 22,6 & 22,0 & 50,5 & 45,0 & 41,0 \\
Temmuz & 8,8 & 3,9 & 0,0 & 23,5 & 26,7 & 24,9 & 45,9 & 29,8 & 35,7 \\
Ağustos & 6,3 & 9,8 & 0,7 & 23,4 & 26,3 & 26,6 & 46,5 & 37,1 & 34,5 \\
Eylül & 6,8 & 0 & 61,6 & 20,4 & 20,9 & 19,9 & 46,4 & 35,0 & 50,3 \\
Ekim & 29,0 & 14,1 & 18,6 & 14,9 & 16,7 & 13,3 & 59,1 & 49,4 & 63,8 \\
Kasım & 49,6 & 66,7 & 43,6 & 5,7 & 6,7 & 8,7 & 72,1 & 66,6 & 72,1 \\
Aralık & 33,2 & 44,4 & 28,8 & 0,9 & 2,0 & 2,0 & 78,0 & 75,7 & 78,6 \\
\hline Top/Ort & 337,6 & 305,2 & 323,2 & 12,2 & 13,5 & 12,7 & 60,3 & 53,1 & 57,0 \\
\hline
\end{tabular}

*T.C. Devlet Meteoroloji İșleri Genel Müdürlüğü. Ankara 2009.

Çizelge 2. Deneme alanından alınan toprak örneklerinde yapılan fizikokimyasal analiz sonuçları

Table 2. Physical and chemical characteristic of experimental fields

\begin{tabular}{|ccccccccccc|}
\hline Yıllar & $\begin{array}{c}\text { Derinlik } \\
(\mathrm{cm})\end{array}$ & Tekstür & $\begin{array}{c}\text { Su ile } \\
\text { Doymușluk } \\
(\%)\end{array}$ & $\begin{array}{c}\text { Tuz } \\
(\%)\end{array}$ & $\mathrm{pH}$ & $\begin{array}{c}\text { Kireç } \\
(\%)\end{array}$ & $\begin{array}{c}\text { Yarayıșlı } \\
\text { Fosfor } \\
\mathrm{P}_{2} \mathrm{O}_{5} \\
\left(\mathrm{~kg} \mathrm{da}^{-1}\right)\end{array}$ & $\begin{array}{c}\text { Değișebilir } \\
\text { Potasyum } \\
\mathrm{K}_{2} \mathrm{O} \\
\left(\mathrm{kg} \mathrm{da}^{-1}\right)\end{array}$ & $\begin{array}{c}\text { Toplam } \\
\mathrm{N}\end{array}$ & $\begin{array}{c}\text { Organik } \\
\text { Madde } \\
(\%)\end{array}$ \\
\hline 2007 & $0-20$ & Killi-tınlı & 50 & 0,0 & 8,07 & 10,3 & 8,65 & 245 & 0,08 & 1,01 \\
& $20-40$ & Killi-tınlı & 53 & 0,0 & 8,04 & 8,31 & 11,02 & 190 & 0,17 & 1,14 \\
2008 & $0-20$ & Killi-tınlı & 54 & 0,0 & 7,85 & 9,00 & 7,85 & 160 & 0,06 & 1,25 \\
& $20-40$ & Killi-tınlı & 60 & 0.8 & 8,00 & 10,0 & 6,45 & 125 & 0,15 & 1,02 \\
\hline
\end{tabular}

\section{BULGULAR VE TARTIȘMA}

Üç farklı sıra üzeri aralığın (20, 30 ve 40 cm) ve dört farklı azot (N) dozunun uygulandığı 03M142 hibrit çerezlik ayçiçeği genotipinde bitki boyu, tabla çapı, bin tane ağırlığı, bitkide tane verimi, kabuk oranı, yağ oranı, protein oranı ve dekara tane verimi özellikleri incelenmiștir. Bu özelliklere ilișkin varyans analiz sonuçları Çizelge 3'de, ortalamalar ve Duncan grupları ise Çizelge 4, 5 ve 6'da gösterilmiștir. Çizelge 3'de görüldüğü gibi, her iki yılın birleștirilmiș verileriyle yapılan varyans analizi sonuçlarına göre, uygulamaların bitki boyu, tabla çapı ve bin tane ağırlığı üzerine etkileri yıllar arasında istatistiki olarak farklılık göstermemiștir. Bitkide tane verimi, hasat indeksi, kabuk oranı, yağ oranı, protein oranı ve dekara verimde yıllar arasında istatistiki olarak farklılık belirlenmiștir.
Her iki yılın ortalaması değerlendirildiğinde, artan azot dozlarıyla beraber bitki boyunda artıș gözlenmiștir. Ancak 12 kg da-1 azot dozu uygulanan parsellerden alınan 157,2 cm ortalama değer ile $8 \mathrm{~kg} \mathrm{da-1}$ azot uygulanan parsellerden elde edilen 156,8 cm ortalama değer birbirine yakın sonuçlar vermiș ve aynı grup içerisinde yer almıșlardır. Bitki boyuna ilișkin bulgularımız artan azot dozlarıyla beraber ayçiçeğinde bitki boyunun arttığını bildiren Al-Thabet (2006) artan sıra üzeri mesafe ve artan azot dozlarıyla bitki boyunun arttığını bildiren Jahangir vd., (2006), Ali vd., (2004) ve artan azot dozlarının bitki boyunda artıșa sebep olduğunu kaydeden Lauretti vd., (2007)' nin sonuçlarıyla da benzerlik göstermektedir. Ancak artan bitki sıklığının ayçiçeğinde bitki boyunu arttırdığını bildiren Gubbels 
Çizelge 3. Farkı sıra üzeri aralıkları ve azot dozları uygulamalarının çerezlik ayçiçeği genotipinde bazı verim özelliklerine ilișkin varyans analizi sonuçları

Table 3. Summary of the analysis of variance for several variables of confectionery sunflower genotype grown under different intra-row spacing and nitrogen doses

\begin{tabular}{|c|c|c|c|c|c|c|c|c|c|c|}
\hline & Yillar & $\begin{array}{l}\text { Bitki } \\
\text { boyu }\end{array}$ & $\begin{array}{l}\text { Tabla } \\
\text { çapı }\end{array}$ & $\begin{array}{l}\text { Bin tane } \\
\text { ağırlığı }\end{array}$ & $\begin{array}{l}\text { Hasat } \\
\text { indeksi }\end{array}$ & $\begin{array}{l}\text { Kabuk } \\
\text { oranı }\end{array}$ & $\begin{array}{l}\text { Bitkide } \\
\text { tane } \\
\text { verimi }\end{array}$ & $\begin{array}{l}\text { Protein } \\
\text { oranı }\end{array}$ & $\begin{array}{l}\text { Yağ } \\
\text { oranı }\end{array}$ & $\begin{array}{l}\text { Dekara } \\
\text { tane } \\
\text { verimi }\end{array}$ \\
\hline & 2007 & * & & * & ** & ** & * & & & * \\
\hline \multirow{4}{*}{$\begin{array}{l}\text { Sıra Üzeri } \\
\text { Aralık (A) }\end{array}$} & & & & & & & & & & \\
\hline & 2008 & & & & $* *$ & & & & $* *$ & $* *$ \\
\hline & Ort. & & * & & $* *$ & $* *$ & $* *$ & & * & $* *$ \\
\hline & 2007 & ** & & $\star *$ & ** & * & ** & & & $* *$ \\
\hline \multicolumn{11}{|l|}{ Azot } \\
\hline \multirow[t]{2}{*}{ Dozları (B) } & 2008 & ** & & * & ** & * & ** & & & $* *$ \\
\hline & Ort. & $* *$ & & $\star *$ & $* \star$ & $* *$ & $* *$ & & & $* *$ \\
\hline$Y_{I I}(Y)$ & & & & & * & $* *$ & $* *$ & $* *$ & & $* *$ \\
\hline \multirow[t]{3}{*}{$A \times B$} & 2007 & & & & ** & & & & & $* *$ \\
\hline & 2008 & & & & ** & & & & & $* *$ \\
\hline & Ort. & & & & $* *$ & * & & & * & $* *$ \\
\hline$A x Y$ & & * & & & & ** & & & & ** \\
\hline Bxy & & $* *$ & & & & & ** & & & $\star *$ \\
\hline$A x B x y$ & & & & & & & & & & $* *$ \\
\hline
\end{tabular}

*: 0.05 düzeyinde, ${ }^{* *}: 0.01$ düzeyinde önemli

ve Dedio (1986)'nun sonuçlarıyla benzerlik göstermemektedir.

Tabla çapında her iki yılın ortalaması incelendiğinde artan sıra üzeri aralıklarla beraber yani bitki sıklığının azalmasıyla büyüme gözlenmiștir. Bununla beraber 30 ve $40 \mathrm{~cm}$ sıra üzeri aralıkta elde edilen değerler sırasıyla $20,7 \mathrm{~cm}$ ve $20,8 \mathrm{~cm}$ olup istatistiki olarak aynı grup içerisinde yer almıșlardır. Tabla çapıyla ilgili elde ettiğimiz sonuçlar, çerezlik ayçiçeğinde bitki sıkığının ve azotun etkilerinin araștırdığı denemesinde artan bitki sıklığının tabla çapını düșürdüğünü belirten Kıllı (2004) ile benzerlik göstermektedir. Yine birçok araștırıcı yapmıș oldukları çalıșmalarında, artan bitki sıklığıyla beraber ayçiçeğinde tabla çapının daraldığını saptamıșlardır (Zubriski ve Zimmerman, 1974; Holt ve Zentner, 1985; Kıllı ve Özdemir, 2001; Al-Thabet, 2006). Bunların yanı sıra yapılan diğer çalıșmalarda artan azot dozlarının ayçiçeğinde tabla çapını artırdığı farklı araștırıcılar tarafından ortaya konmuștur (Ali vd., 2004; Özer vd., 2004). Bu çalıșmada ise azot (N) dozlarının tabla çapı üzerine etkisi istatistiki olarak önemli çıkmamıștır.

Bin tane ağırlığı ayçiçeğinde verimi etkileyen en önemli karakterlerden biridir. Bu özellik her iki yılda da artan azot dozlarıyla beraber artıs göstermiștir. Her iki yıldan elde edilen değerlerin ortalaması incelendiğinde 8 ve $12 \mathrm{~kg}_{\mathrm{da}}{ }^{-1} \mathrm{~N}$ uygulanan parsellerden elde edilen değerler sırasıyla 129,2 g ve 128,4 g olup aynı Duncan gruplandırmasında aynı harflerle ifade edilmișlerdir. Çalıșmada azotun artan dozları kontrol uygulamasına göre bin tane ağırlığını artırmıștır. Bunun sebebi ise bitkinin daha fazla azota erișebilme imkânı bulmasıyla vejetatif ve generatif kısımlarının daha fazla gelișim göstermesi olarak açıklanabilir (Gholinezhad vd., 2009). Bin tane ağırlığına ilișkin saptanan bulgular azotun artan 
Çizelge 4. Farkı sıra üzeri aralıkların ve azot dozlarının çerezlik ayçiçeği genotipinin bitki boyu tabla çapı ve bin tane ağırığı üzerine etkisi

Table 4. Impact of different intra-row spacing and nitrogen doses on plant height, head diameter and 1000 seed weight of the confectionary sunflower

\begin{tabular}{|c|c|c|c|c|c|c|c|c|c|c|}
\hline \multirow{2}{*}{$\begin{array}{c}\text { Sira Üzeri } \\
\text { Aralık }\end{array}$} & & \multicolumn{3}{|c|}{ Bitki Boyu $(\mathrm{cm})$} & \multicolumn{3}{|c|}{ Tabla Çapı $(\mathrm{cm})$} & \multicolumn{3}{|c|}{ Bin tane ağırlığı (g) } \\
\hline & & 2007 & 2008 & Ort. & 2007 & 2008 & Ort. & 2007 & 2008 & Ort. \\
\hline \multirow{4}{*}{$20 \mathrm{~cm}$} & $\mathrm{~N}_{0}$ & 126,0 & 135,0 & 130,5 & 17,7 & 18,6 & 18,2 & 104,8 & 95,4 & 100,1 \\
\hline & $\mathrm{N}_{1}$ & 136,0 & 159,0 & 147,5 & 18,8 & 16,9 & 17,8 & 117,5 & 101,6 & 109,5 \\
\hline & $\mathrm{N}_{2}$ & 154,0 & 162,0 & 158,0 & 20,3 & 17,8 & 19,1 & 120,0 & 123,3 & 121,7 \\
\hline & $\mathrm{N}_{3}$ & 157,7 & 159,7 & 158,7 & 18,2 & 21,4 & 19,8 & 138,5 & 118,5 & 128,5 \\
\hline \multicolumn{2}{|c|}{$20 \mathrm{~cm}$ ortalama } & 143,4 & 153,9 & 148,7 & 18,7 & 18,7 & $18,7 \mathrm{~b}$ & 120,2 & 109,7 & 114,9 \\
\hline \multirow{4}{*}{$30 \mathrm{~cm}$} & $\mathrm{~N}_{0}$ & 134,7 & 138,3 & 136,5 & 20,6 & 20,4 & 20,5 & 109,0 & 110,2 & 109,6 \\
\hline & $N_{1}$ & 144,3 & 152,3 & 148,3 & 23,4 & 21,0 & 22,2 & 126,6 & 122,2 & 124,4 \\
\hline & $\mathrm{N}_{2}$ & 159,7 & 153,0 & 156,3 & 20,0 & 21,5 & 20,8 & 126,1 & 131,7 & 128,9 \\
\hline & $\mathrm{N}_{3}$ & 161,3 & 142,3 & 151,8 & 19,1 & 19,4 & 19,2 & 133,5 & 122,3 & 127,9 \\
\hline $30 \mathrm{~cm}$ ortalam & & 150,0 & 146,5 & 148,3 & 20,8 & 20,6 & 20,7 a & 123,8 & 121,6 & 122,7 \\
\hline \multirow{4}{*}{$40 \mathrm{~cm}$} & $\mathrm{~N}_{0}$ & 146,7 & 134,7 & 140,7 & 22,3 & 19,1 & 20,7 & 114,2 & 112,1 & 113,2 \\
\hline & $\mathrm{N}_{1}$ & 149,3 & 151,3 & 150,3 & 21,3 & 21,5 & 21,4 & 133,0 & 121,0 & 127,0 \\
\hline & $\mathrm{N}_{2}$ & 161,7 & 150,7 & 156,2 & 21,0 & 19,2 & 20,1 & 140,8 & 133,6 & 137,2 \\
\hline & $\mathrm{N}_{3}$ & 166,0 & 156,3 & 161,2 & 22,8 & 19,0 & 20,9 & 139,8 & 117,7 & 128,8 \\
\hline \multicolumn{2}{|c|}{$40 \mathrm{~cm}$ ortalama } & 155,9 & 148,3 & 152,1 & 21,8 & 19,7 & 20,8 a & 131,9 & 121,1 & 126,5 \\
\hline \multicolumn{2}{|l|}{ Azot Dozları } & 2007 & 2008 & Ort. & 2007 & 2008 & Ort. & 2007 & 2008 & Ort. \\
\hline \multicolumn{2}{|l|}{ No Ortalama } & 135,8 & 136,0 & $135,9 \mathrm{C}$ & 20,2 & 19,3 & 19,8 & 109,3 & 105,9 & $107,6 \mathrm{C}$ \\
\hline \multicolumn{2}{|l|}{ N 1 Ortalama } & 143,2 & 154,2 & 148,7 b & 21,2 & 19,8 & 20,5 & 125,7 & 114,9 & $120,3 \mathrm{~b}$ \\
\hline \multirow{2}{*}{\multicolumn{2}{|c|}{$\begin{array}{l}\mathrm{N}_{2} \text { Ortalama } \\
\mathrm{N}_{3} \text { Ortalama }\end{array}$}} & 158,4 & 155,2 & 156,8 a & 20,4 & 19,5 & 19,9 & 128,9 & 129,5 & 129,2 a \\
\hline & & 161,7 & 152,8 & 157,2 a & 20,0 & 19,9 & 20,0 & 137,3 & 119,5 & 128,4 a \\
\hline \multicolumn{2}{|l|}{ YIllar } & 149,8 & 149,6 & 149,7 & 20,5 & 19,7 & 20,1 & 125,3 & 117,5 & 121,4 \\
\hline \multicolumn{2}{|l|}{ CV $(\%)$} & 2,59 & 5,90 & 4,55 & 11,18 & 10,71 & 10,96 & 5,81 & 12,33 & 9,44 \\
\hline
\end{tabular}

*:0,05 düzeyinde önemli, **:0,01 düzeyinde önemli, Aynı harflerle gösterilen ortalamalar arasındaki fark önemli değildir, $N_{0}$ :

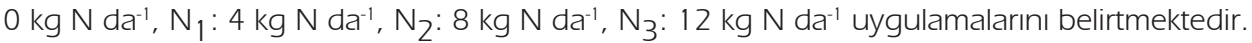

dozlarının ayçiçeğinde bin tane ağırlığında artıșa sebep olduğunu bildiren Özer vd., (2004), Ali vd., (2004), Jahangir vd., (2006) ve Al-Thabet (2006)'in sonuçlarılya benzerlik göstermektedir.

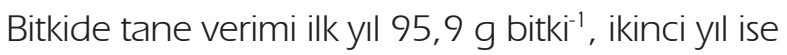

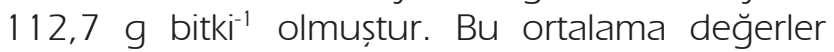
arasındaki fark istatistiki olarak önemli bulunmuștur $(p<0,01)$. Yıllar arasında gözlenen bu farklılık 2007 yılında yağıșın çiçeklenme zamanında olmasına ve polen tașınmasını olumsuz etkilemesine bağlanabilir. Bitkide tane verimi her iki yılda da artan sıra üzeri aralık ve azot dozlarıyla beraber artıș göstermiștir. Artan sıra üzeri mesafeyle beraber ayçiçeği, azot ve diğer bitki besin maddelerini daha kolay elde edebilir. Böylece bitki vejetatif ve generatif aksamını daha fazla geliștirme olanağı bulur. Bitkide tane verimine ilișkin elde ettiğimiz veriler, artan azot dozlarının ayçiçeğinde bitki bașına tane verimini artıııcı özellik gösterdiğini bildiren Kıllı (2004) ve hem artan azot dozlarının hem de artan sıra üzeri mesafenin bitkide tane verimini artırdığını bildiren Al-Thabet (2006)' in sonuçlarılyla benzerlik göstermektedir.
Hasat indeksi yıllar arasında farklılık göstermiș ve bu farklılık istatistiki olarak önemli bulunmuștur $(p<0,05)$. Ortalama hasat indeksi değeri \% 42,7 olurken 2008 yılında \% 41,6 olmuștur. Hasat indeksi değerleri her iki yılda da sıra üzeri aralıklar ve azot dozları arttıkça artıș göstermiștir. Denemede bitki sıklığı arttıkça ve verilen $N$ dozu düștükçe hasat indeksi azalma göstermektedir. Bunun sebebi de bitkinin vejetatif ve generatif organları arasında paylașılan asimile edilmiș maddelerin daha az olması olabilir. Duncan (1985), artan bitki sıklığıyla beraber yaprak alanı indeksinin ve kuru madde veriminin arttığını, ancak bitkiler arasında yașanan yüksek rekabetten dolayı hasat indeksinin düștüğünü saptamıștır. Hasat indeksi değerinin bitki sıkığının artmasıyla azalma gösterdiği Zaffaroni ve Schneiter (1991) ile Gholinezhad vd., (2009) tarafindan da ileri sürülmüștür, 
Çizelge 5. Farklı sıra üzeri aralıkların ve azot dozlarının çerezlik ayçiçeği genotipinin hasat indeksi, kabuk oranı ve bitkide tane verimi üzerine etkisi

Table 5. Impact of different intra-row spacing and nitrogen doses on harvest index, hull ratio and seed yield per head of the confectionary sunflower

\begin{tabular}{|c|c|c|c|c|c|c|c|c|c|c|}
\hline \multirow{2}{*}{\multicolumn{2}{|c|}{$\begin{array}{l}\text { Sira Üzeri } \\
\text { Aralık }\end{array}$}} & \multicolumn{3}{|c|}{ Hasat indeksi (\%) } & \multicolumn{3}{|c|}{ Kabuk oranı (\%) } & \multicolumn{3}{|c|}{ Bitkide tane verimi $\left(g\right.$ bit $\left.^{-1}\right)$} \\
\hline & & 2007 & 2008 & Ort, & 2007 & 2008 & Ort, & 2007 & 2008 & Ort, \\
\hline \multirow{4}{*}{$20 \mathrm{~cm}$} & $\mathrm{~N}_{0}$ & $32,6 \mathrm{e}$ & $31,6 f^{* *}$ & 32,1 & 41,7 & 48,1 & 44,9 & 67,5 & 80,5 & 74,0 \\
\hline & $N_{1}$ & $41,0 d$ & $39,9 \mathrm{e}$ & 40,5 & 39,3 & 45,9 & 42,6 & 87,3 & 85,9 & 86,6 \\
\hline & $\mathrm{N}_{2}$ & $44,9 \mathrm{~b}$ & $42,7 d$ & 43,8 & 49,3 & 48,5 & 48,9 & 83,3 & 115,1 & 99,2 \\
\hline & $\mathrm{N}_{3}$ & 46,3ab & $44,6 \mathrm{bc}$ & 45,4 & 46,3 & 46,5 & 46,4 & 92,9 & 117,5 & 105,2 \\
\hline \multicolumn{2}{|c|}{$20 \mathrm{~cm}$ Ort, } & 41,2 & 39,7 & 40,5 & $44,2 b^{*}$ & 47,3 & 45,7 & $82,8 b^{*}$ & 99,7 & 91,2 \\
\hline \multirow{4}{*}{$30 \mathrm{~cm}$} & $\mathrm{~N}_{0}$ & $31,6 \mathrm{e}$ & $31,1 \mathrm{f}$ & 31,3 & 48,3 & 48,0 & 48,2 & 89,9 & 101,2 & 95,5 \\
\hline & $\mathrm{N}_{1}$ & $41,7 d$ & $39,2 \mathrm{e}$ & 40,5 & 42,1 & 44,9 & 43,6 & 109,7 & 123,1 & 116,4 \\
\hline & $\mathrm{N}_{2}$ & $44,5 \mathrm{bc}$ & $42,4 d$ & 43,4 & 46,0 & 47,4 & 46,7 & 100,6 & 138,5 & 119,6 \\
\hline & $\mathrm{N}_{3}$ & $46,3 \mathrm{ab}$ & $43,5 \mathrm{~cd}$ & 44,9 & 41,9 & 44,1 & 42,9 & 103,9 & 129,7 & 116,8 \\
\hline \multicolumn{2}{|c|}{30 cm Ort, } & 41,0 & 39,1 & 40,0 & $44,6 \mathrm{~b}$ & 46,1 & 45,4 & 101,0 a & 123,1 & 112,1 \\
\hline \multirow{4}{*}{$40 \mathrm{~cm}$} & $\mathrm{~N}_{0}$ & $42,2 \mathrm{~cd}$ & $42,7 d$ & 42,4 & 46,9 & 47,6 & 47,3 & 99,5 & 105,3 & 102,4 \\
\hline & $N_{1}$ & $44,6 \mathrm{~b}$ & $45,2 \mathrm{~b}$ & 44,9 & 46,2 & 46,1 & 46,2 & 111,7 & 113,6 & 112,6 \\
\hline & $\mathrm{N}_{2}$ & 48,3 a & 47,9 a & 48,1 & 48,5 & 47,3 & 47,9 & 108,7 & 119,7 & 114,2 \\
\hline & $\mathrm{N}_{3}$ & 48,5 a & 48,3 a & 48,4 & 46,9 & 46,5 & 46,7 & 97,0 & 121,9 & 109,4 \\
\hline \multicolumn{2}{|c|}{$40 \mathrm{~cm}$ Ort, } & 45,9 & 46,0 & 45,9 & 47,1 a & 46,9 & 47,0 & 104,2 a & 115,1 & 109,7 \\
\hline \multicolumn{2}{|c|}{ Azot Dozları } & 2007 & 2008 & Ort, & 2007 & 2008 & Ort, & 2007 & 2008 & Ort, \\
\hline \multicolumn{2}{|c|}{ No Ortalama } & 35,5 & 35,1 & 35,3 & 45,6 a & $47,9 a^{*}$ & 46,7 & $85,6 \mathrm{~b}$ & $95,7 b^{* *}$ & 90,7 \\
\hline \multirow{2}{*}{\multicolumn{2}{|c|}{$\begin{array}{l}N_{1} \text { Ortalama } \\
N_{2} \text { Ortalama }\end{array}$}} & 42,4 & 41,5 & 41,9 & $42,5 \mathrm{~b}$ & $45,7 \mathrm{~b}$ & 44,1 & 102,9 a & 107,5 b & 105,2 \\
\hline & & 45,9 & 44,3 & 45,1 & 47,9 a & 47,7 a & 47,9 & 97,5 а & 124,4 a & 110,9 \\
\hline \multicolumn{2}{|c|}{$\mathrm{N}_{3}$ Ortalama } & 47,0 & 45,5 & 46,3 & $45,0 \mathrm{ab}$ & $45,7 \mathrm{~b}$ & 45,4 & 97,9 a & 123,0 a & 110,5 \\
\hline \multirow{2}{*}{\multicolumn{2}{|c|}{$\begin{array}{l}\text { Yıllar } \\
\text { ortalama } \\
\text { CV }(\%) \\
\end{array}$}} & 42,7 a & $41,6 b^{*}$ & 42,2 & $45,3 \mathrm{~b}$ & $46,8 a^{* *}$ & 46,1 & $95,9 \mathrm{~b}$ & $112,7 a^{* *}$ & 104,3 \\
\hline & & 1,96 & 1,20 & 1,64 & 4,33 & 2,39 & 3,14 & 8,44 & 11,79 & 10,55 \\
\hline
\end{tabular}

*:0,05 düzeyinde önemli, **:0,01 düzeyinde önemli, Aynı harflerle gösterilen ortalamalar arasındaki fark önemli değildir, $\mathrm{N}_{0}: 0 \mathrm{~kg} \mathrm{~N} \mathrm{da}{ }^{-1}, \mathrm{~N}_{1}: 4 \mathrm{~kg} \mathrm{~N} \mathrm{da}^{-1}, \mathrm{~N}_{2}: 8 \mathrm{~kg} \mathrm{~N} \mathrm{da}^{-1}, \mathrm{~N}_{3}: 12 \mathrm{~kg} \mathrm{~N} \mathrm{da}^{-1}$ uygulamalarını belirtmektedir.

Kabuk oranı değerleri istatistiki olarak her iki yılda farklılık göstermiștir ( $p<0,01) .2008$ yllında \% 46,8 ile 2007 yllına göre daha fazla değer vermiștir. Kabuk oranına ilișkin sonuçlar kısaca değerlendirildiğinde, çerezlik çeșitlerin ayırııı bir özelliği olan yüksek kabuk oranı değerleri elde edilmiștir. Ayrıca $4 \mathrm{~kg} \mathrm{da}^{-1} \mathrm{~N}$ dozu uygulanan parsellerden elde edilen değerler kontrol parsellerine göre düșük olmuștur. Birçok araștırıcı da çerezlik çeșitlerin yüksek kabuk oranına sahip olduklarını bildirmektedirler (İncekara, 1972; Karadoğan ve Özgödek, 1994; Atakiși, 1999). Kaya (2006) yağlık çeșitlerle yapılan çalıșmasında kabuk oranını Sanbro çeșidinde \% 25,08, Tarsan 1018 çeșidinde \% 24,38 ve Özdemir Bey çeșidinde \% 24,30 olarak belirlemiștir. Materyal olarak kullanılan yağılık çeșitlerden elde edilen değerler çalıșmamızda kullandığımız çerezlik ayçiçeğinin ortalama kabuk değeriyle (\% 46,7) karșılaștırıldığında; çerezlik çeșitlerin kabuk oranlarının yağıklara göre yüksek olduğu görülmektedir.

Azotun yüksek dozlarının ayçiçeğinde yağ oranını düșürdüğünü bildiren birçok kaynak bulunmaktadır. Yağ oranına ait her iki yılda ki ortalamalar incelendiğinde iki yıl arasında istatistiki olarak farklılık belirlenmemiștir. İki yllın ortalaması değerlendirildiğinde istatistiki olarak sıra üzeri aralıklar $x$ azot dozları interaksiyonu önemli olmuștur $(p<0,05)$. Farklı sıra üzeri aralıklarda azot dozları yağ oranını kontrole göre artırmıștır. Elde ettiğimiz değerler, azotun yağ oranını azaltıcı etki gösterdiğini söyleyen Özer vd., (2004), Al-Thabet (2006) ve Zubriski ve Zimmerman (1974)'la uyușmamaktadır. Ancak Montemurro ve De Giorgio (2005) azotun bitkinin ilk gelișim dönemlerinde alınması ve depo edilen azotun çiçeklenmeden sonra harekete geçmesiyle azot kullanım etkinliği artmıș olabileceğinden azotun artan dozlarının yağ oranı üzerinde artırıcı etkisi olabileceğini belirtmișlerdir. Eğer bitki çiçeklenme dönemi bașladıktan sonra topraktan azotu alırsa, azotun yağ oranını düșürücü etki gösterdiği de Steer vd., (1984) ve Ruffo vd., (2003) tarafindan bildirilmiștir. Araștırmamızda azotu ekimden önce ve minyatür tabla olușum așamasında vermiș olmamızın yağ oranını artıııc etkiye sebep olduğu söylenebilir.

Çerezlik ayçiçeğinde protein oranının yüksek olması istenen bir özelliktir. Lofgren (1997), çerezlik 
ayçiçeğinde kabuklardan ayrılmıș içte protein oranını \% 26,6-30,8 olarak bildirmiștir. Elde edilen sonuçlar incelendiğinde, sıra üzeri aralıkları, azot dozları ve sıra üzeri aralık x azot dozu interaksiyonu protein oranı üzerinde istatistiki olarak önemli olmamıștır. Ancak protein oranına yönelik her iki yılda elde edilen ortalama değerler istatistiki olarak fark göstermiștir $(p<0,01)$. Protein oranı ilk yıl \% 29,7, ikinci yıl \% 26, 9 olarak gözlenmiștir. Protein oranının 2007 yılında daha yüksek olmasının sebebi Temmuz ayı sıcaklığının 2008 yılına göre daha fazla olması (2007 Temmuz ayı ortalama sıcaklığı 26,7 ${ }^{\circ} \mathrm{C}, 2008$ Temmuz ayı ortalama sıcaklığı 24,9 ${ }^{\circ} \mathrm{C}$ ) sebebiyle çiçeklenme öncesinde topraktan alıp depo ettiği azotu daha etkin biçimde kullanması olarak açıklanabilir. Escalante vd., (1998) ayçiçeğinde verim artıșını ve N kullanım etkinliğini azotun topraktan çiçeklenme öncesinde alınıp depo edilerek çiçek açımı ve tozlanma esnasında kullanılmasına bağlamıș, aynı zamanda hava sıcaklığının tozlanma esnasında kuru ve sıcak olmasının bu etkiyi daha da artırdığını belirtmiștir. Protein oranına ilișkin verilerimiz, azotun artan dozlarının protein oranını artırdığını bildiren Özer vd., (2004), Ayub vd., (1998),
Blamey ve Chapman (1981)' in sonuçlarıly benzerlik göstermemektedir.

Dekara tane verimi her iki çeșitte bitki sıklığının artmasıyla ve artan azot dozlarıyla beraber artıș göstermiștir. Dekara tane verimine ilișkin değerler yıllar arasında farklılık göstermiș olup istatistiki olarak önemli bulunmusttur $(p<0,01)$. Her iki yılda da sıra üzeri aralıklar $x$ azot dozları interaksiyonu istatistiki olarak önemli olmuștur $(p<0,01)$. Tabla çapı, bin tane ağırlığı ve bitkide tane verimi bitki sıklığının artmasıyla azalmasına rağmen, her iki yılda bitki sıklığının en fazla olduğu parsellerde ve azotun en yüksek dozunun uygulandığı parsellerden en fazla verim alınmıștır. Bitki sıklığının verim üzerine etkisi ile ilgili yapılan çalıșmalarda oldukça farklı sonuçlar alınmıștır. Zubriski ve Zimmerman (1974), Ruffo vd., (2003), Al-Thabet (2006), Ali vd., (2004), Jahangir (2006) ve Beg vd., (2007) gibi bitki sıklığı arttıkça verimin arttığını belirten araștırıcılar ile yaptığımız çalıșmadan elde edilen sonuçar benzerlik göstermesine karșllık, Holt ve Champell (1984), Miller ve Fick (1978) ve Gubbels ve Dedio (1989) gibi bitki sıklığının verimde bir artıșa neden olmadığını belirten diğer araștırıcıların bulguları ile çelișmektedir.

Çizelge 6. Farkı sıra üzeri aralıkların ve azot dozlarının çerezlik ayçiçeği genotipinin protein oranı, yağ oranı ve dekara tane verimi üzerine etkisi

Table 6. Impact of different intra-row spacing and nitrogen doses on protein ratio, oil ratio and seed yield of the confectionary sunflower

\begin{tabular}{|c|c|c|c|c|c|c|c|c|c|c|}
\hline \multirow{2}{*}{$\begin{array}{c}\text { Sira } \\
\text { Üzeri } \\
\text { Aralık }\end{array}$} & & \multicolumn{3}{|c|}{ Protein Oranı (\%) } & \multicolumn{3}{|c|}{ Yağ Oranı (\%) } & \multicolumn{3}{|c|}{ Dekara Tane verimi $\left(\mathrm{kg} \mathrm{da}^{-1}\right)$} \\
\hline & & 2007 & 2008 & Ort. & 2007 & 2008 & Ort. & 2007 & 2008 & Ort. \\
\hline \multirow{4}{*}{$20 \mathrm{~cm}$} & $\mathrm{~N}_{0}$ & 29,0 & 24,9 & 26,9 & 43,6 & 42,7 & $43,1 \mathrm{bc}^{*}$ & $222,3 \mathrm{ef}$ & $303,7 \mathrm{c} * *$ & 263,0 \\
\hline & $N_{1}$ & 27,8 & 26,5 & 27,2 & 42,3 & 44,0 & $43,1 \mathrm{bc}$ & $235,0 \mathrm{bc}$ & 352,7 b & 293,8 \\
\hline & $\mathrm{N}_{2}$ & 28,8 & 27,6 & 28,2 & 44,9 & 45,2 & $45,1 \mathrm{abc}$ & 257,7 a & 406,3 a & 332,0 \\
\hline & $\mathrm{N}_{3}$ & 29,5 & 28,2 & 28,9 & 43,7 & 45,4 & 44,6 abc & 262,7 a & 410,3 a & 336,5 \\
\hline \multicolumn{2}{|c|}{$20 \mathrm{~cm}$ ortalama } & 28,8 & 26,8 & 27,8 & 43,6 & 44,3 & 43,9 & 244,4 & 368,3 & 306,3 \\
\hline \multirow{4}{*}{$30 \mathrm{~cm}$} & $\mathrm{~N}_{0}$ & 29,2 & 27,1 & 28,2 & 42,3 & 42,1 & $42,2 \mathrm{~cd}$ & $198,3 \mathrm{~h}$ & $220,3 \mathrm{~h}$ & 209,3 \\
\hline & $\mathrm{N}_{1}$ & 29,4 & 25,7 & 27,5 & 45,9 & 45,2 & 45,6 ab & $207,7 \mathrm{~g}$ & $228,3 \mathrm{~g}$ & 218,0 \\
\hline & $\mathrm{N}_{2}$ & 31,5 & 25,4 & 28,5 & 44,1 & 44,3 & 44,2 abc & $220,3 \mathrm{f}$ & $283,3 \mathrm{~d}$ & 251,8 \\
\hline & $\mathrm{N}_{3}$ & 33,1 & 25,9 & 29,5 & 48,0 & 44,6 & 46,3 a & $227,3 \mathrm{de}$ & $281,0 \mathrm{~d}$ & 254,2 \\
\hline \multicolumn{2}{|c|}{$30 \mathrm{~cm}$ ortalama } & 30,8 & 26,0 & 28,4 & 45,1 & 44,1 & 44,6 & 213,4 & 253,3 & 233,3 \\
\hline \multirow{4}{*}{$40 \mathrm{~cm}$} & $\mathrm{~N}_{0}$ & 30,2 & 27,3 & 28,7 & 43,9 & 41,0 & $42,5 \mathrm{~cd}$ & $194,3 \mathrm{~h}$ & $257,3 \mathrm{f}$ & 225,8 \\
\hline & $\mathrm{N}_{1}$ & 31,9 & 26,2 & 29,1 & 43,1 & 41,9 & $42,5 \mathrm{~cd}$ & $231,7 \mathrm{~cd}$ & $266,0 \mathrm{e}$ & 248,8 \\
\hline & $\mathrm{N}_{2}$ & 27,0 & 29,8 & 28,4 & 41,0 & 39,4 & $40,2 d$ & 233,0 bc & $269,3 \mathrm{e}$ & 251,2 \\
\hline & $\mathrm{N}_{3}$ & 29,3 & 27,9 & 28,6 & 45,3 & 40,9 & $43,1 \mathrm{bc}$ & $237,3 \mathrm{~b}$ & $271,0 \mathrm{e}$ & 254,2 \\
\hline \multicolumn{2}{|c|}{40 cm ortalama } & 29,6 & 27,8 & 28,7 & 43,3 & 40,8 & 42,1 & 224,1 & 265,9 & 245,0 \\
\hline \multicolumn{2}{|c|}{ Azot Dozları } & 2007 & 2008 & Ort. & 2007 & 2008 & Ort. & 2007 & 2008 & Ort. \\
\hline \multicolumn{2}{|c|}{$\mathrm{N}_{0}$ Ortalama } & 29,4 & 26,4 & 27,9 & 43,3 & 41,9 & 42,6 & 205,0 & 260,4 & 232,7 \\
\hline \multicolumn{2}{|c|}{ N 1 Ortalama } & 29,7 & 26,1 & 27,9 & 43,7 & 43,7 & 43,7 & 224,8 & 282,3 & 253,6 \\
\hline \multicolumn{2}{|c|}{$\mathrm{N}_{2}$ Ortalama } & 29,1 & 27,6 & 28,4 & 43,3 & 42,9 & 43,2 & 237,0 & 319,7 & 278,3 \\
\hline \multicolumn{2}{|c|}{$\mathrm{N}_{3}$ Ortalama } & 30,7 & 27,3 & 29,0 & 45,7 & 43,6 & 44,7 & 242,4 & 320,8 & 281,6 \\
\hline \multirow{2}{*}{\multicolumn{2}{|c|}{$\begin{array}{l}\text { Yillar Ortalama } \\
\text { CV }(\%)\end{array}$}} & $29,7 a$ & $26,9 b^{* *}$ & 28,3 & 44,0 & 43,1 & 43,6 & $227,3 \mathrm{~b}$ & $295,8 a^{* *}$ & 261,6 \\
\hline & & 5,45 & 6,27 & 5,86 & 3,41 & 2,16 & 3,00 & 2,05 & 1,73 & 1,87 \\
\hline
\end{tabular}

*:0,05 düzeyinde önemli, **:0,01 düzeyinde önemli, Aynı harflerle gösterilen ortalamalar arasındaki fark önemli değildir. $\mathrm{N}_{0}: 0 \mathrm{~kg} \mathrm{~N} \mathrm{da} a^{-1}, \mathrm{~N}_{1}: 4 \mathrm{~kg} \mathrm{~N} \mathrm{da}^{-1}, \mathrm{~N}_{2}: 8 \mathrm{~kg} \mathrm{~N} \mathrm{da}^{-1}, \mathrm{~N}_{3}: 12 \mathrm{~kg} \mathrm{~N} \mathrm{da}^{-1}$ uygulamalarını belirtmektedir. 


\section{SONUC}

Çerezlik ayçiçeğine uygulanan farklı sıra üzeri aralık ve azot dozlarının verim, verim bileșenleri, protein ve yağ oranı üzerine etkisinin incelendiği araștırma bulguları topluca değerlendirilmiștir. Incelenen özelliklerin 2007 ve 2008 yıllarındaki istatistiki analizlerinde konuların ve bunların interaksiyonlarının önemlilik durumları farklılık göstermiștir. Bunun en önemli nedeni olarak yıllar arasında görülen yağıș miktarlarının çok farklı olması ve dolayısıyla nispi nemde ve sıcaklıkta ortaya çıkan farklılıklar görülmektedir.

Araștırma sonucunda farklı sıra üzeri aralık ve farklı azot dozlarının 03M142 çerezlik ayçiçeği genotipinin verim ve verim ögeleri üzerine etkileri değerlendirildiğinde șunlar söylenebilir. Sıra üzeri aralığın daralması ve bununla beraber azot dozlarının da artması verim artıșına sebep olmuștur. 20, 30 ve $40 \mathrm{~cm}$ sıra üzeri aralıklarda artan azot dozlarılya beraber dekara verimde artıș görülmüștür.

Dekara tane verimi ayçiçeğinde önemli bir faktördür, ancak çerezlik ayçiçeğinde bitki sıklığının artması dekara tane verimini artırmıș olsa da, tohum büyüklüğünü olumsuz yönde etkilemektedir. Denemeden elde edilen sonuçlara göre 03M 142 genotipi için $40 \mathrm{~cm}$ sıra üzeri aralık ve $4 \mathrm{~kg} \mathrm{da}^{-1} \mathrm{~N}$ dozu uygundur, Çerezlik çeșit ekiminde farklı sıra üzeri aralıklarda farklı azot dozları uygun sonucu verebilmektedir. Elbette bu durum çeșitlere göre değișim göstermektedir. Ayrıca bazı verim kriterleri sadece çeșit, azot dozundan ya da sıra üzeri aralıktan etkilenirken, bazı verim kriterlerinde bu üçünün etkileșimi ya da herhangi ikisinin etkileșim göstermesiyle farklılık görülmüștür.

\section{Teșekkür}

Bu çalıșma, Sibel DAY tarafından Ankara Üniversitesi Fen Bilimleri Enstitüsü Tarla Bitkileri Anabilim Dalında yapılan doktora tezinin bir kısmını kapsamaktadır.

\section{KAYNAKLAR}

Anonim (2009). Meteoroloji Genel Müdürlüğü. Ankara.

Anonim (2014). http://mww.tuik.gov.tr. Erișim tarihi:20.02.2014

Al-Thabet S S (2006). Effect of plant spacing and nitrogen level on growth and yield of sunflower (Helianthus annuus L.) Journal of Saud. Univ., 19(1): 1-11.

Ali H, Randhawa S A, Yousaf M (2004). Quantitative and qualitative traits of sunflower (Helianthus annuus L.) as influenced by planting dates and nitrogen application. International Journal of Agriculture and Biology, 6(2): 410-412.
Atakiși I (1999). Yağ Bitkileri Yetiștirme ve Islahı. T.Ü. Tekirdağ Ziraat Fakültesi Yayınları. Yayın no: 148 Ders kitabı no: 10, s. 14.

Ayub M, Tanveer Z, lqbal Z, Sharar M S, Azam M (1998). Response of two sunflower (Helianthus annuus L.) cultivars to different levels of nitrogen. Pakistan Journal of Biological Sciences, 1(4): 348-350

Beg A, Pourdad S S, Alipour S (2007). Row and plant spacing effects on agronomic performance of sunflower in warm and semi-cold areas of Iran. Helia, 30(47): 99-104.

Blamey F P C, Chapman J (1981). Protein, oil, and energy yields of sunflower as affected by $N$ and $P$ fertilization. Agronomy Journal, 73:583-587.

De Giorgio D, Montemurro V, Fornaro F (2007). Four-year field experiment on nitrogen application to sunflower genotypes grown in semiarid conditions. Helia, 30(47): 15-26.

Düzgüneș $O$, Kesici T, Kavuncu $O$, Gürbüz F (1987). Araștırma ve Deneme Metotları (İstatistik Metotları II). A.Ü. Ziraat Fakültesi Yayınları: 1021. Ankara, s. 295.

Escalante J A, Rodriguez M T, De Haro A, Fereres E C (1998). Accusition, partioning and remobilization of nitrogen and their relationship to seed yield in Mediterranean sunflower. Helia, 21(29):81-94.

Gholinezhad E, Aynaband A, Ghorthapeh A H, Noormohamadi G, Bernousi I (2009). Study of the effect of drought stres on yield, yield components and harvest index of sunflower hybrid Iroflor at different levels of nitrogen and plant population. Notulae Botanicae Horti Agrobotanici ClujNapoca, 37(2): 85-94.

Gubbels G H, Dedio W (1 986). Effect of plant density and soil fertility on oilseed sunflower genotypes. Can. J. Plant Sci., 66:521-527

Gubbels G H, Dedio W (1989). Effect of plant density and seeding date on early- and late-maturing sunflower hybrids. Can. J. Plant Sci., 69:1251-1254

Holt N W, Campbell S J (1984). Effect of plant density on the agronomic performance of sunflower on dryland. Can. J. Plant Sci., 64:599-605

Holt N W, Zentner R P (1985). Effect of plant density and row spacing on agronomic performance and economic returns of nonoilseed sunflower in southeastern Saskatchewan. Can. J. Plant Sci., 65:501-509.

Incekara F (1972). Yağ Bitkileri ve Islahı. Cilt:2. Ege Üniversitesi Ziraat Fakültesi Yayınları. No:83 İzmir, s.81.

Jahangir A A, Mondal R K, Nada K, Afroze S, Hakim M (2006). Response of nitrogen and phosphorus fertilizer and plant spacing on growth and yield contributing character of sunflower. Bangladesh J. Sci. Ind. Res., 41(1-2): 33-40.

Kaya M D (2006). Farklı gelișme dönemlerinde uygulanan sulamaların ayçiçeğinde (Helianthus annuus L.) verim ve verim ögelerine etkileri. Doktora tezi. 95 sayfa.

Kıllı F, Özdemir G (2001). Yağlık melez ayçiçeği çeșitlerinin bitki sıklığına tepkisi. Türkiye 4. Tarla Bitkileri Kongresi, Cilt 2, s. 29-32, Tekirdağ.

Kıllı $F$ (2004). Influence of different nitrogen levels on productivity of oilseed and confection sunflowers (Helianthus annuUs L.) under varying plant populations. International Journal of Agriculture and Biology, 6(4):594-598. 
Laureti D, Pieri S, Vannozzi G P, Turi M, Giovanardi R (2007). Nitrogen fertilization in wet and dry climate. Helia, 30(47):135-140

Lofgren J R (1997). Sunflower for confectionery food, bird food and pet food. In A. A. Schneiter (ed.) Sunflower Technology and Production. ASA. SCSA. and SSSA Monoghraph. No:35. Madison. WI. p.747-764.

Miller J F, Fick G N (1978). Influence of plant population on performance of sunflower Hybrids. Can. J. Plant Sci., 58:597-600.

Montemurro F, De Giorgio D (2005). Quality and nitrogen use efficiency of sunflower grown at different nitrogen levels under Mediterranean conditions. Journal of Plant Nutrition, 28:335-350.

Özer H, Polat T, Öztürk E (2004). Response of irrigated sunflower (Helianthus annuus L.) hybrids to nitrogen fertilization: growth, yield and yield components. Plant Soil Environment, 50(5):205-211.

Ruffo M L, García F O, Bollero G A, Fabrizzi K, Ruiz R (2003). Nitrogen balance approach to sunflower fertilization. Communications In Soil Science and Plant Analysis, 34 (1718):2645-2657.

Schneiter A A, Miller J F (1981). Description of sunflower growth stages. Crop Science, 21: 901-903.

Steer B T, Hocking P J, Kortt A A, Roxburgh C M (1984). Nitrogen nutrition of sunflower (Helianthus annuus L.): Yield components, the timing of their establishment and seed characteristics in response to nitrogen supply. Field Crops Research, 9: 219-236.

Zaffaroni E, Schneiter A A (1991). Sunflower production as influenced by plant type, plant population and row arrangement. Agron. J., 63:113-118.

Zubriski J C, Zimmerman D C (1974). Effect of nitrogen, phosphorus and plant density on sunflower. American Society of Agronomy, 66:798-801 